\title{
Danske landbrugslandskaber gennem 2000 år - fra digevoldinger til støtteordninger
}

Anmeldt af Søren M. Kristiansen, Geologisk Institut, Aarhus Universitet

Det danske landskabs historie og udvikling fra vores tidsregnings begyndelse og frem til i dag, bliver $i$ en ny bog beskrevet af en lang række forskere. Bogens fokus er på ændringer i landskabets udseende og anvendelse, som de i dag kan aflæses i så forskellige kilder som pollen og stednavne.

Den er et resultat af et stort projekt - AGRAR2000 - hvor en række forskere har beskrevet, hvorfor og hvor hurtigt vores landskab har været i forandring.

Og dette har krævet en bred vifte af fagpersoner, som beskæftiger sig med landskabet og derfor kan bidrage med viden fra fagområder som arkæologi, geografi, historie, landbrug og geologi.

\section{Bogens opbygning}

I bogen præsenteres 9 undersøgelsesområder med $3 \mathrm{i}$ hver af de hovedlandskabstyper, som findes her i landet, nemlig skov, landbrug og hede. Projektets idé var hermed at belyse disse landskabers forskellige udvikling de seneste 2.000 år. Både de generelle forandringer for hele landet, og også hvordan de enkelte landsdele har forandret sig.

I det første letlæste kapitel gennemgås klimaets udvikling i perioden. Herefter følger kapitler, som beskriver udviklingen $i$ arealdækningen (fx skov, landbrug, hede)

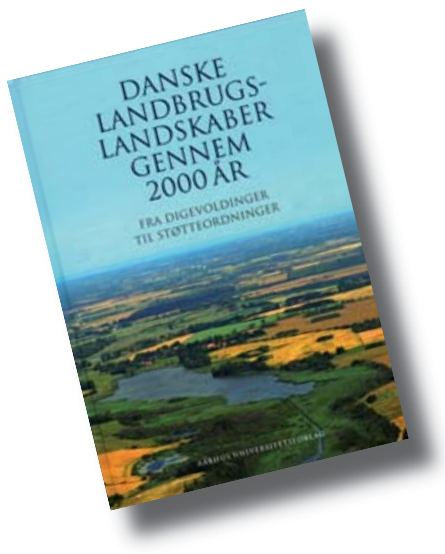

for hele landet og specielt for de 9 undersøgte områder. Dernæst kommer en række kapitler, som gennemgår strukturudviklingen i landbruget fra de jernalderens inddigede marker til vore dages intensivt drevne monokulturer. Og alt sammen med fokus på, hvordan landbruget, hedebruget og husdyrenes græsning har påvirket det landskab, som vi ser i dag. Til slut kommer der et sammenfattende kapitel, som giver en syntese af alle de forskellige tilgange, som forskerne har, og som har resulteret i en samlet beskrivelse af, hvordan vores landskab er blevet formet og forandret de seneste to årtusinder.

Ændringerne i landskabet og vores udnyttelse heraf, som de beskrives i bogen, har de seneste århundrede været hurtige og store - og med store konsekvenser for landskabet og naturen. Formålet med bogen har dog tydeligvis været at beskrive denne udvikling, og der fremkommer kun ringe debat om, hvorvidt disse ændringer er positive eller negative. En sådan debat vil sandsynligvis også forsvinde i en bog propfyldt med fakta og informationer og hører rettelig hjemme $i$ andre sammenhænge. Men her er i hvert fald præsenteret en mængde viden til en diskussion om, hvad vi vil med landskabet $\mathrm{i}$ fremtiden.

\section{Generelt om bogen}

Selve bogen har et flot og gennemført layout og er derfor meget læsevenlig. Hvis man skulle efterlyse noget i bogen, så var det en kort introduktion til de personer, som skriver i bogen, samt et stikordsregister, som kunne gøre det lettere at udnytte bogen, når man senere står med et konkret spørgsmål. Men ellers er der kun små og ubetydelige fejl og mangler i den tykke bog.

Alt $i$ alt er bogen interessant læsning og kan anbefales. Den henvender sig især til geologer, som til dagligt arbejder med eller har interesse i forvaltningen af det åbne land. Den er god, hvis man ønsker overblik over de utallige menneskelige påvirkninger, som vores moderne landskab er et resultat af, og kan fx være en hjælp i udvælgelsen af en lokal plejeforanstaltning, som skal genskabe og beskytte en given naturtype. Af særlig interesse for geologer er de første par kapitler om klimaet og udvikling i pollen og jordbund samt det sidste kapitel, som giver overblik over strukturelle ændringer i landbruget og vores skiftende udnyttelse af naturen.

Redigeret af Bent Odgaard og Jørgen Rydén Rømer, 301 sider rigt illustreret, pris 398 $k r$., udgivelsesår 2009, Aarhus Universitetsforlag, ISBN: 978-87-7934-420-4. 